\title{
Modelling the Effect of Solution Composition and Temperature on the Conductivity of Zinc Electrowinning Electrolytes
}

\author{
Zulin Wang ${ }^{1}{ }^{\oplus}$, Arif Tirto Aji ${ }^{1}$, Benjamin Paul Wilson ${ }^{1} \oplus$, Steinar Jørstad ${ }^{2}$, Maria Møll ${ }^{2}$ and Mari Lundström ${ }^{1, *}$ \\ 1 Department of Chemical and Metallurgical Engineering (CMET), Aalto University School of Chemical \\ Engineering, P.O. Box 16200, FI-00076 Aalto, Finland; zulin.wang@aalto.fi (Z.W.); arif.aji@aalto.fi (A.T.A.); \\ ben.wilson@aalto.fi (B.P.W.) \\ 2 Boliden Odda Zinc Smelter, Eitrheim, NO-5750 Odda, Norway; steinar.jorstad@boliden.com (S.J.); \\ maria.moll@boliden.com (M.M.) \\ * Correspondence: mari.lundstrom@aalto.fi
}

Citation: Wang, Z.; Aji, A.T.; Wilson, B.P.; Jørstad, S.; Møll, M.; Lundström, M. Modelling the Effect of Solution Composition and Temperature on the Conductivity of Zinc Electrowinning Electrolytes. Metals 2021, 11, 1824 https://doi.org/10.3390/ met11111824

Academic Editor: Juan Creus

Received: 21 September 2021 Accepted: 9 November 2021 Published: 13 November 2021

Publisher's Note: MDPI stays neutral with regard to jurisdictional claims in published maps and institutional affiliations.

Copyright: (c) 2021 by the authors. Licensee MDPI, Basel, Switzerland. This article is an open access article distributed under the terms and conditions of the Creative Commons Attribution (CC BY) license (https:// creativecommons.org/licenses/by/ $4.0 /)$.

\begin{abstract}
Zinc electrowinning is an energy-intensive step of hydrometallurgical zinc production in which ohmic drop contributes the second highest overpotential in the process. As the ohmic drop is a result of electrolyte conductivity, three conductivity models (Aalto-I, Aalto-II and Aalto-III) were formulated in this study based on the synthetic industrial electrolyte conditions of $\mathrm{Zn}\left(50-70 \mathrm{~g} / \mathrm{dm}^{3}\right)$, $\mathrm{H}_{2} \mathrm{SO}_{4}\left(150-200 \mathrm{~g} / \mathrm{dm}^{3}\right), \mathrm{Mn}\left(0-8 \mathrm{~g} / \mathrm{dm}^{3}\right), \mathrm{Mg}\left(0-4 \mathrm{~g} / \mathrm{dm}^{3}\right)$, and temperature, $\mathrm{T}\left(30-40{ }^{\circ} \mathrm{C}\right)$. These studies indicate that electrolyte conductivity increases with temperature and $\mathrm{H}_{2} \mathrm{SO}_{4}$ concentration, whereas metal ions have negative effects on conductivity. In addition, the interaction effects of temperature and the concentrations of metal ions on solution conductivity were tested by comparing the performance of the linear model (Aalto-I) and interrelated models (Aalto-II and Aalto-III) to determine their significance in the electrowinning process. Statistical analysis shows that Aalto-I has the highest accuracy of all the models developed and investigated in this study. From the industrial validation, Aalto-I also demonstrates a high level of correlation in comparison to the other models presented in this study. Further comparison of model Aalto-I with the existing published models from previous studies shows that model Aalto-I substantially improves the accuracy of the zinc conductivity empirical model.
\end{abstract}

Keywords: zinc electrowinning; conductivity model; energy consumption; industrial validation

\section{Introduction}

Zinc is widely used in the production of a number of key materials and applications, including brass, galvanized steel, sacrificial anodes, and batteries. Currently, more than $80 \%$ of the world's primary zinc is produced through hydrometallurgical processes that typically incorporate electrowinning as the final step. Zinc electrowinning is normally conducted at a temperature between 30 and $40{ }^{\circ} \mathrm{C}$ in a zinc sulfate electrolyte that is composed of $\mathrm{H}_{2} \mathrm{SO}_{4}\left(150-200 \mathrm{~g} / \mathrm{dm}^{3}\right), \mathrm{Zn}\left(50-70 \mathrm{~g} / \mathrm{dm}^{3}\right), \mathrm{Mn}\left(4-8 \mathrm{~g} / \mathrm{dm}^{3}\right)$, and other impurities such as $\mathrm{Mg}$ and $\mathrm{Ca}$. The main reactions during the electrowinning process are zinc deposition on the cathode (Equation (1)) and oxygen evolution on the anode (Equation (2)), although hydrogen evolution as an additional side reaction may also decrease the current efficiency at the cathode (Equation (3)).

$$
\begin{array}{cc}
\text { Cathode }: \mathrm{Zn}^{2+}+2 \mathrm{e}^{-} \rightarrow \mathrm{Zn} & E^{0}=-0.76 \mathrm{~V} \text { vs. SHE } \\
\text { Anode }: 2 \mathrm{H}_{2} \mathrm{O} \rightarrow 4 \mathrm{H}^{+}+\mathrm{O}_{2}+4 \mathrm{e}^{-} & E^{0}=+1.23 \mathrm{~V} \text { vs. SHE } \\
\text { Cathode }: 2 \mathrm{H}^{+}+2 \mathrm{e}^{-} \rightarrow \mathrm{H}_{2} & E^{0}=0 \mathrm{~V} \text { vs. SHE }
\end{array}
$$

where $E^{0}$ is the standard potential of the reaction and SHE is the standard hydrogen electrode.

Under normal process conditions, hydrogen evolution is reduced to a minimum rate in order to avoid excessive current usage; therefore, the overall reaction that occurs 
in the electrowinning cell and thermodynamical cell voltage $\left(E_{T}\right)$ can be outlined as in Equation (4):

$$
\mathrm{Zn}^{2+}+\mathrm{H}_{2} \mathrm{O} \rightarrow \mathrm{Zn}+2 \mathrm{H}^{+}+\frac{1}{2} \mathrm{O}_{2} \quad \mathrm{E}_{\mathrm{T}}=1.99 \mathrm{~V}
$$

In practice, total cell voltage $\left(E_{\text {cell }}\right)$ is the sum of thermodynamical cell voltage $\left(E_{T}\right)$ and several overpotentials related to the cathodic and anodic reactions $\left(E_{\eta}\right)$, the ohmic drop of the electrolytes $\left(E_{\text {ohmic }}\right)$, and the resistance of the electric circuit $\left(E_{R}\right)$, Equation (5):

$$
E_{\text {cell }}=E_{T}+E_{\eta}+E_{\text {ohmic }}+E_{R}
$$

Industrial zinc electrowinning processes are generally operated at a total cell voltage of 3.3-3.5 V, with a current density in the range of $400-600 \mathrm{~A} / \mathrm{m}^{2}$ and typical current efficiencies of $89-92 \%$ [1]. Since the anodic reaction contributes more than $1.9 \mathrm{~V}$ of the total cell voltage [1], previous research has primarily focused on the development of new anode materials for reducing the oxygen evolution reaction (OER) overpotential [2-10]. Nevertheless, $\mathrm{Pb}-\mathrm{Ag}$ alloys remain the most widely utilized anodes due to their low cost and favorable corrosion resistance properties in sulfuric acid media [11,12].

Electrolyte ohmic drop is the second most significant contributor to the total energy consumption in electrowinning and it is affected by both electrolyte conductivity and inter-electrode distances [13]. When the electrolyte is the medium for electrical current $(I)$ flow, Ohm's law can be written as Equation (6), where $E_{\text {ohmic }}$ and $R_{\text {elec }}$ are the ohmic drop and resistance, respectively. In addition, the electrolyte resistance, as a function of specific conductivity $(\kappa)$ (as the inverse of specific resistivity $(\rho)$ ), can be written as Equation (7):

$$
\begin{gathered}
E_{\text {ohmic }}=I \cdot R_{\text {elec }} \\
R_{\text {elec }}=\frac{\rho \cdot l}{A}=\frac{l}{(\kappa \cdot A)}
\end{gathered}
$$

By combining Equations (6) and (7), the ohmic drop voltage can be formulated as in Equation (8):

$$
E_{\text {ohmic }}=I \cdot \frac{l}{(\kappa \cdot A)}=j \cdot \frac{l}{\kappa}
$$

where $j$ is current density, $l$ is inter-electrode distance. A is the area of electrode and $l$ is the inter-electrode distance.

Meanwhile, the fundamental correlation of conductivity to electrolyte concentration is shown in Equation (9) [14]:

$$
\kappa=\frac{l}{A}\left(\frac{F^{2}}{R T}\right) \sum_{i} z_{i}^{2} D_{i} C_{i}
$$

where $z_{i}$ is the valence, $D_{i}$ is the diffusion coefficient and $C_{i}$ is the concentration $\left(\mathrm{mol} / \mathrm{dm}^{3}\right)$, $\mathrm{F}$ is the Faraday constant $(96485 \mathrm{C} / \mathrm{mol}), \mathrm{R}$ is the universal gas constant $\left(8.314 \mathrm{~J} \cdot \mathrm{K}^{-1} \cdot \mathrm{mol}^{-1}\right)$, and $T$ is the absolute temperature $(K)$.

Several previously published conductivity models are shown in Equations (10)-(14) [15-19]:

$$
\begin{gathered}
\kappa_{\text {Nikiforov }}=123+189.3\left[\mathrm{H}_{2} \mathrm{SO}_{4}\right]-77.8[\mathrm{Zn}]+1.14 \mathrm{~T} \\
\kappa_{\text {Scott et al }}=320+2.7\left[\mathrm{H}_{2} \mathrm{SO}_{4}\right](\mathrm{T}-35)+196\left(\left[\mathrm{H}_{2} \mathrm{SO}_{4}\right]-1.12\right) \\
-111\left([\mathrm{Zn}]+[\mathrm{Mn}]+[\mathrm{Mg}]+0.5\left[\mathrm{NH}_{4}^{+}\right]-1.25\right)
\end{gathered}
$$




$$
\begin{aligned}
\kappa_{\text {Mahon et al }=-} & 107.9[\mathrm{Zn}]-539.0\left[\mathrm{H}_{2} \mathrm{SO}_{4}\right]-18.14[\mathrm{Zn}]^{2}-63.80\left[\mathrm{H}_{2} \mathrm{SO}_{4}\right]^{2} \\
& -10.27[\mathrm{Zn}]\left[\mathrm{H}_{2} \mathrm{SO}_{4}\right]+167.3[\mathrm{Zn}]^{2}\left[\mathrm{H}_{2} \mathrm{SO}_{4}\right]+0.585[\mathrm{Zn}](\mathrm{T} \\
+ & 273)+124.6[\mathrm{Zn}]\left[\mathrm{H}_{2} \mathrm{SO}_{4}\right]^{2}-67.62[\mathrm{Zn}]^{2}\left[\mathrm{H}_{2} \mathrm{SO}_{4}\right]^{2} \\
+ & 3.345\left[\mathrm{H}_{2} \mathrm{SO}_{4}\right](\mathrm{T}+273)-1.341[\mathrm{Zn}]\left[\mathrm{H}_{2} \mathrm{SO}_{4}\right](\mathrm{T}+273) \\
\kappa_{\text {Tozawa et al }}=4+ & 1.15 \mathrm{~T}+2.82\left[\mathrm{H}_{2} \mathrm{SO}_{4}\right] \mathrm{T}+344.2\left[\mathrm{H}_{2} \mathrm{SO}_{4}\right]-45.1\left[\mathrm{H}_{2} \mathrm{SO}_{4}\right]^{2} \\
+ & 28.6\left([\mathrm{Zn}]+\left[\mathrm{Mg}^{2}\right)^{2}+([\mathrm{Zn}]+[\mathrm{Mg}])\right. \\
( & \left.-1.14 \mathrm{~T}-105.8\left[\mathrm{H}_{2} \mathrm{SO}_{4}\right]-22.4\right) \\
\kappa_{\text {Aliofkhazraei }}= & -0.741[\mathrm{Zn}]-0.004857\left[\mathrm{H}_{2} \mathrm{SO}_{4}\right]^{2}+2.453\left[\mathrm{H}_{2} \mathrm{SO}_{4}\right] \\
& +84.602 \log \mathrm{T}+0.726 \mathrm{~T}+24.023
\end{aligned}
$$

where $\kappa$ is in $\mathrm{mS} / \mathrm{cm}$, all concentrations are in $\mathrm{g} / \mathrm{dm}^{3}$, and temperature $T$, is in ${ }^{\circ} \mathrm{C}$.

From the modelling studies above, it can be recognized that from a fundamental perspective, that conductivity is a sum of the individual effects related to temperature $T$, acid concentration $\left[\mathrm{H}_{2} \mathrm{SO}_{4}\right]$, and metal ion concentrations. Nevertheless, the previously published models have two major weaknesses: Firstly, the exclusion of minor impurities [15-17], and secondly, the utilization of a single coefficient value to represent zinc and other impurities $[18,19]$. Recent conductivity modelling studies in copper and silver electrolytes have demonstrated that every metal element ion present has an independent coefficient that can affect the electrolyte conductivity [20-22]. As a result, the main objective of this study is to develop an improved zinc electrolyte conductivity model, increasing prediction accuracy by taking into account the independent effects of metal impurities-such as $\mathrm{Mn}$ and $\mathrm{Mg}$ - along with the typical process parameters of zinc concentration, acidity, and temperature.

\section{Materials and Methods}

Conductivity measurement experiments were conducted with a series of synthetic electrolytes over a range of chemical compositions and temperatures that were selected as being representative of typical industrial zinc electrowinning processes (Table 1). Electrolytes were prepared using zinc sulfate $\left(\mathrm{ZnSO}_{4} \cdot 7 \mathrm{H}_{2} \mathrm{O}, \geq 99 \%\right.$, VWR Chemicals, Belgium), Magnesium sulfate $\left(\mathrm{MgSO}_{4} \cdot 7 \mathrm{H}_{2} \mathrm{O}, \geq 99.5 \%\right.$, Merck KGaA, Germany), Manganese sulfate $\left(\mathrm{MnSO}_{4} \cdot \mathrm{H}_{2} \mathrm{O}, \geq 99.5 \%\right.$, VWR Chemicals, Belgium), and sulfuric acid $\left(\mathrm{H}_{2} \mathrm{SO}_{4}, 95-97 \%\right.$, Merck, Germany). All solutions were prepared with Millipore Milli-Q deionized water $\left(\leq 2 \mu \mathrm{S} / \mathrm{cm}\right.$ at $25^{\circ} \mathrm{C}$, EMD Millipore, Finland). The temperature of the electrolytes was controlled by a MGW Lauda MT/M3 circulating water bath (LAUDA, Lauda-Königshofen, Germany).

Table 1. Parameters and levels use in this study.

\begin{tabular}{ccc}
\hline Parameters & Levels & Units \\
\hline$\left[\mathrm{Zn}^{2+}\right]$ & $50,60,70$ & $\mathrm{~g} / \mathrm{dm}^{3}$ \\
{$\left[\mathrm{H}_{2} \mathrm{SO}_{4}\right]$} & $150,175,200$ & $\mathrm{~g} / \mathrm{dm}^{3}$ \\
{$\left[\mathrm{Mn}^{2+}\right]$} & $0,4,8$ & $\mathrm{~g} / \mathrm{dm}^{3}$ \\
{$\left[\mathrm{Mg}^{2+}\right]$} & $0,2,4$ & $\mathrm{~g} / \mathrm{dm}^{3}$ \\
$T$ & $30,35,40$ & ${ }^{\circ} \mathrm{C}$ \\
\hline
\end{tabular}

Conductivity measurements were performed using a Knick Portamess ${ }^{\circledR} 913$ Cond conductivity meter (Knick Elektronische Messgeräte GmbH \& Co. KG, Germany). Prior to measurement, the conductivity meter was calibrated in a standard reference solution (Reagecon, Ireland) with a conductivity of $12.88 \mathrm{mS} / \mathrm{cm}$ at $25^{\circ} \mathrm{C}$. 
The design software MODDE 8.0 (MKS Data Analytics Solutions, Sweden) was utilized for experimental design and data analysis. Full experiments were designed using a linear model with the factors and levels outlined in Table 1, which resulted in a total of 30 individual conductivity measurements with three center points. Additionally, a further 19 measurements were conducted to help reduce any skewness of the data distribution. All models were evaluated using the following parameters: goodness of fit $\left(R^{2}\right)$, accuracy of prediction $\left(Q^{2}\right)$, standard deviation of the response $(S D Y)$, residual standard deviation $(R S D)$, validity, and reproducibility values. Based on these parameters, a good mathematical model is required to have values of $Q^{2}$, with validity and reproducibility values higher than 0.5, 0.25, and 0.5, whilst the difference between $Q^{2}$ and $R^{2}$ should be $<0.3$ [23].

Industrial validation of the models was conducted at Boliden Odda Zinc Smelter, Norway. As shown in Figure 1, four points of measurement were conducted in each of the four cells (A to D) investigated: at the inlet, $1 / 3$ and $2 / 3$ of the cell distance from the inlet, and the outlet. These points were selected to accommodate the possibility of any changes in acid and zinc concentrations induced by the electrowinning process. A sample of electrolyte was also taken for analysis from each point (Table 2) and further used for conductivity measurements at different temperatures.

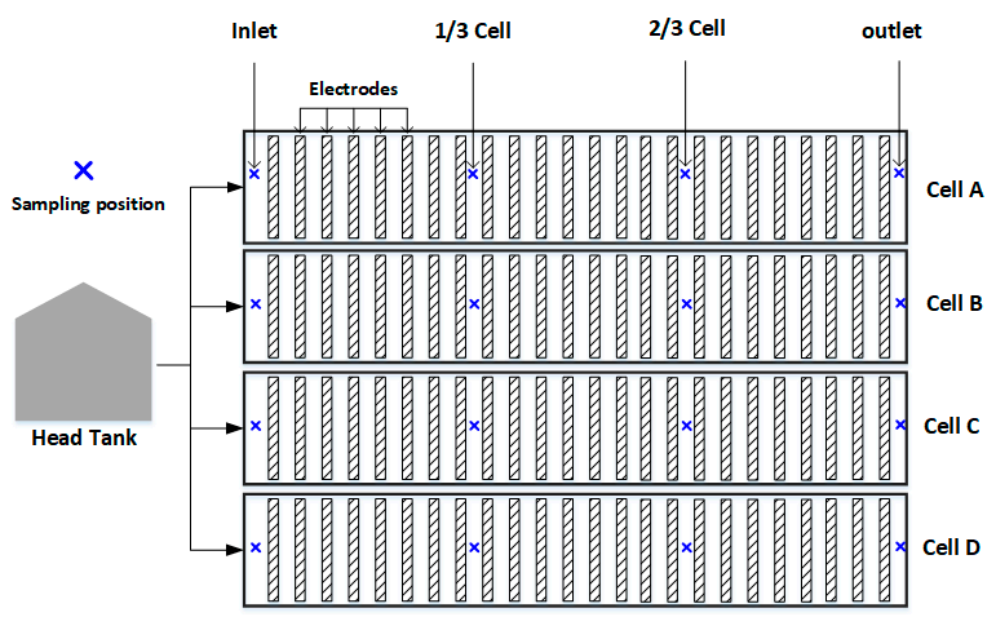

Figure 1. Schematic illustration of cells in the tank house, and the in situ conductivity measurements and sampling points.

Table 2. Composition of industrial electrolytes obtained from Boliden Odda Zinc Smelter.

\begin{tabular}{|c|c|c|c|c|c|c|c|c|}
\hline \multirow{2}{*}{$\begin{array}{l}\text { Sample } \\
\text { ID }\end{array}$} & \multirow{2}{*}{ Cell } & \multirow{2}{*}{ Position } & \multicolumn{6}{|c|}{ Composition $\left(\mathrm{g} / \mathrm{dm}^{3}\right)$} \\
\hline & & & $\mathrm{Zn}$ & $\mathrm{H}_{2} \mathrm{SO}_{4}$ & Mg & Mn & $\mathrm{Na}$ & $\mathrm{Ca}$ \\
\hline 1 & \multirow{5}{*}{ A } & inlet & 52.8 & 189.6 & \multirow{4}{*}{11.8} & \multirow{4}{*}{7.3} & \multirow{16}{*}{$2.3-2.5$} & \multirow{16}{*}{0.4} \\
\hline 2 & & $1 / 3$ & 49.4 & 192.2 & & & & \\
\hline 3 & & $2 / 3$ & 49.0 & 194.9 & & & & \\
\hline 4 & & outlet & 50.3 & 192.2 & & & & \\
\hline 5 & & inlet & 52.6 & 187.7 & \multirow{5}{*}{11.2} & \multirow{5}{*}{7.1} & & \\
\hline 6 & \multirow{4}{*}{ B } & $1 / 3$ & 48.5 & 198.9 & & & & \\
\hline 7 & & $2 / 3$ & 48.5 & 193.2 & & & & \\
\hline 8 & & outlet & 48.9 & 192.8 & & & & \\
\hline 9 & & inlet & 54.3 & 191.0 & & & & \\
\hline 10 & \multirow{3}{*}{$\mathrm{C}$} & $1 / 3$ & 47.2 & 194.1 & \multirow{3}{*}{11.2} & \multirow{3}{*}{7.2} & & \\
\hline 11 & & $2 / 3$ & 49.2 & 193.0 & & & & \\
\hline 12 & & outlet & 50.1 & 193.7 & & & & \\
\hline 13 & \multirow{4}{*}{$\mathrm{D}$} & inlet & 50.1 & 192.2 & \multirow{4}{*}{11.3} & \multirow{4}{*}{7.2} & & \\
\hline 14 & & $1 / 3$ & 46.9 & 193.0 & & & & \\
\hline 15 & & $2 / 3$ & 49.4 & 195.3 & & & & \\
\hline 16 & & outlet & 48.7 & 200.6 & & & & \\
\hline
\end{tabular}




\section{Results and Discussion}

The raw data obtained from conductivity measurements performed with the synthetic electrolyte solutions (Table S1) are shown in groups comprised of $5 \mathrm{mS} / \mathrm{cm}$ intervals in the related histogram (Figure 2). The figure shows that the data distribution is statistically symmetric and unimodal in nature; therefore, it provides an ideal basis for the development of the conductivity model.

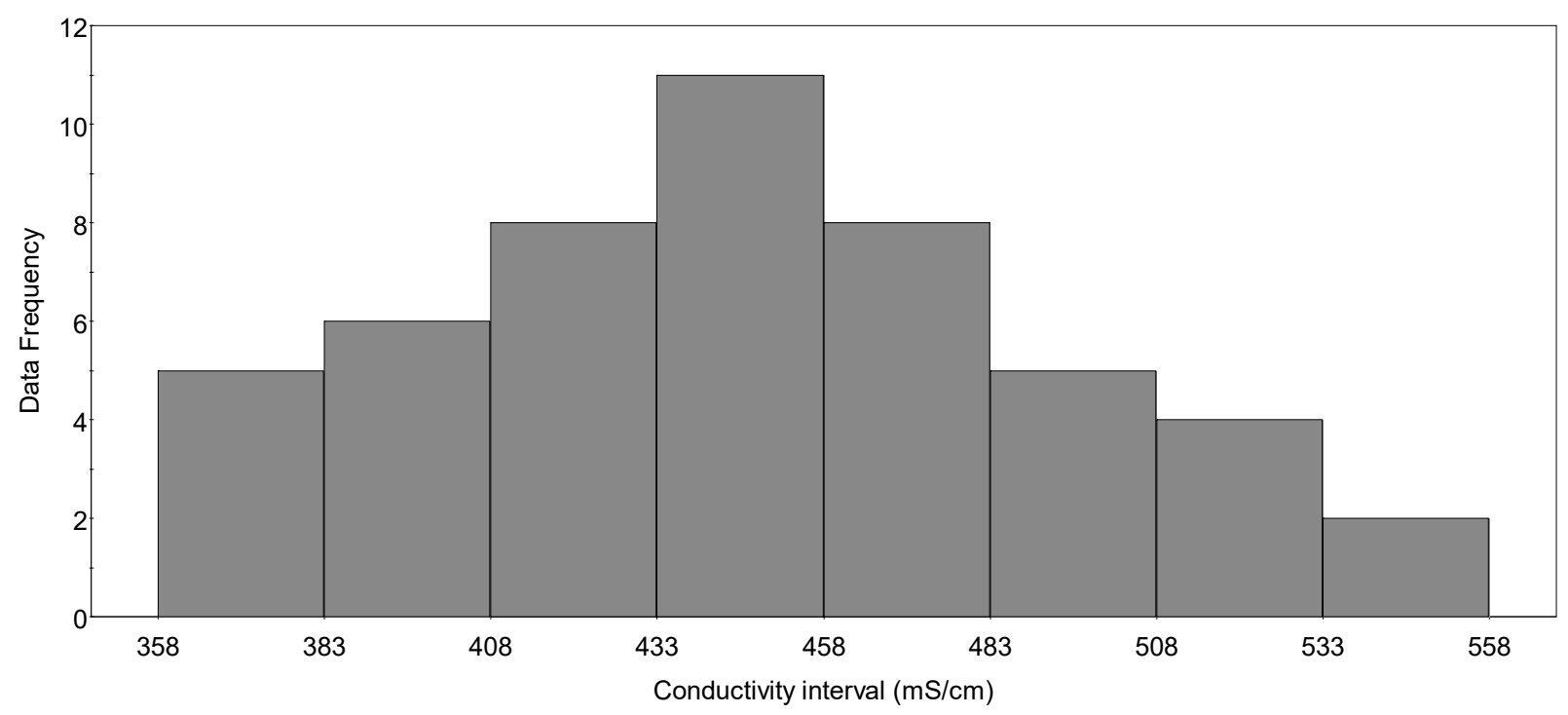

Figure 2. Histogram of the specific conductivity measured from the synthetic zinc electrowinning solutions utilized in this study.

Three models were developed, each with a distinctive character: Aalto-I (Equation (15)) was based on the assumption that each of the investigated parameters had an independent effect on the conductivity, while Aalto-II (Equation (16)) included the model with the interaction effects of concentration and temperature, as previously demonstrated by Scott et al., as shown in Equation (11) [18]. Finally, the Aalto-III (Equation (17)) was developed purely on the valid first-order full-factorial correlation of all parameters. This approach was taken by considering the previous model from Mahon et al., as shown in Equation (12) [16].

\subsection{Aalto Conductivity Models}

The three conductivity models in this study are shown in Equations (15)-(17), whilst the scaled and centered coefficients of these are shown in Figure 3.

$$
\begin{aligned}
\kappa_{\text {Aalto-I }}= & 129.239-2.657[\mathrm{Zn}]+1.687\left[\mathrm{H}_{2} \mathrm{SO}_{4}\right]+5.658 \mathrm{~T}-2.802[\mathrm{Mn}] \\
& -8.116[\mathrm{Mg}] \\
\kappa_{\text {Aalto-II }}= & 346.304+0.626[\mathrm{Zn}]-0.674\left[\mathrm{H}_{2} \mathrm{SO}_{4}\right]+0.6471 \mathrm{~T}-3.668[\mathrm{Mn}] \\
& -7.372[\mathrm{Mg}]-0.092[\mathrm{Zn}] \mathrm{T}+0.061\left[\mathrm{H}_{2} \mathrm{SO}_{4}\right] \mathrm{T} \\
\kappa_{\text {Aalto-III }}=- & 135.072+9.924[\mathrm{Zn}]+1.283\left[\mathrm{H}_{2} \mathrm{SO}_{4}\right]+4.692 \mathrm{~T}-26.705[\mathrm{Mn}] \\
& -8.568[\mathrm{Mg}]-0.028[\mathrm{Zn}]\left[\mathrm{H}_{2} \mathrm{SO}_{4}\right]-0.201[\mathrm{Zn}] \mathrm{T} \\
+ & 0.055\left[\mathrm{H}_{2} \mathrm{SO}_{4}\right] \mathrm{T}+0.668[\mathrm{Mn}] \mathrm{T}
\end{aligned}
$$

where concentrations are in $\mathrm{g} / \mathrm{dm}^{3}, T$ is the temperature in ${ }^{\circ} \mathrm{C}$, and $\kappa$ is in $\mathrm{mS} / \mathrm{cm}$. 

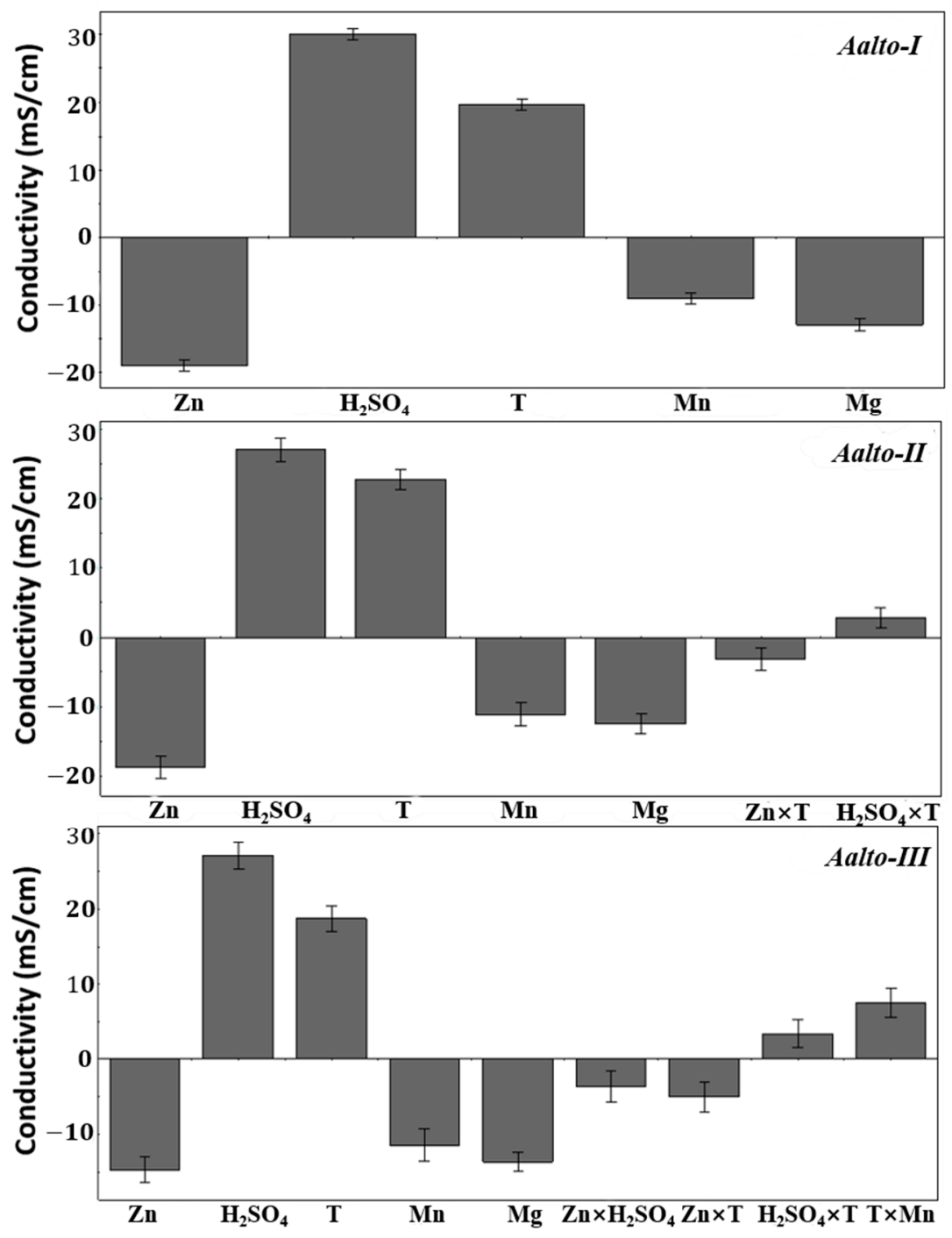

Figure 3. Scaled and centered coefficients of different contributory factors for constructed models Aalto-I, Aalto-II and Aalto-III.

From Figure 3, it can be seen that model Aalto-I clearly has valid coefficients throughout the parameters tested, whereas Aalto-II shows that there are valid correlations between both $\mathrm{Zn}$ and $\mathrm{H}_{2} \mathrm{SO}_{4}$ with temperature. Nevertheless, the correlation of the minor concentrations of $\mathrm{Mn}$ and $\mathrm{Mg}$ to the temperature was deemed to be insignificant, and was thus excluded from the final model. For the pure, full-factorial model of Aalto-III, a strong correlation is observed between $\mathrm{Zn}$ and $\mathrm{H}_{2} \mathrm{SO}_{4}$. Furthermore, similar to the Aalto-II, valid interrelation of the minor concentrations was not observed either with other concentrations, or the temperature.

In order to select the most representative out of these models, a comparison was conducted, as can be observed in Figure 4 . All the models show very accurate predictions of conductivity, with strong values of $\mathrm{R}^{2}, \mathrm{Q}^{2}$, validity, and conductivity. Nevertheless, from the comparison, Aalto-I has the highest values for all the statistical value requirements; in particular, the related validity value is superior to those of the other two models. As a result, Aalto-I was selected as the proposed conductivity model from this study. 


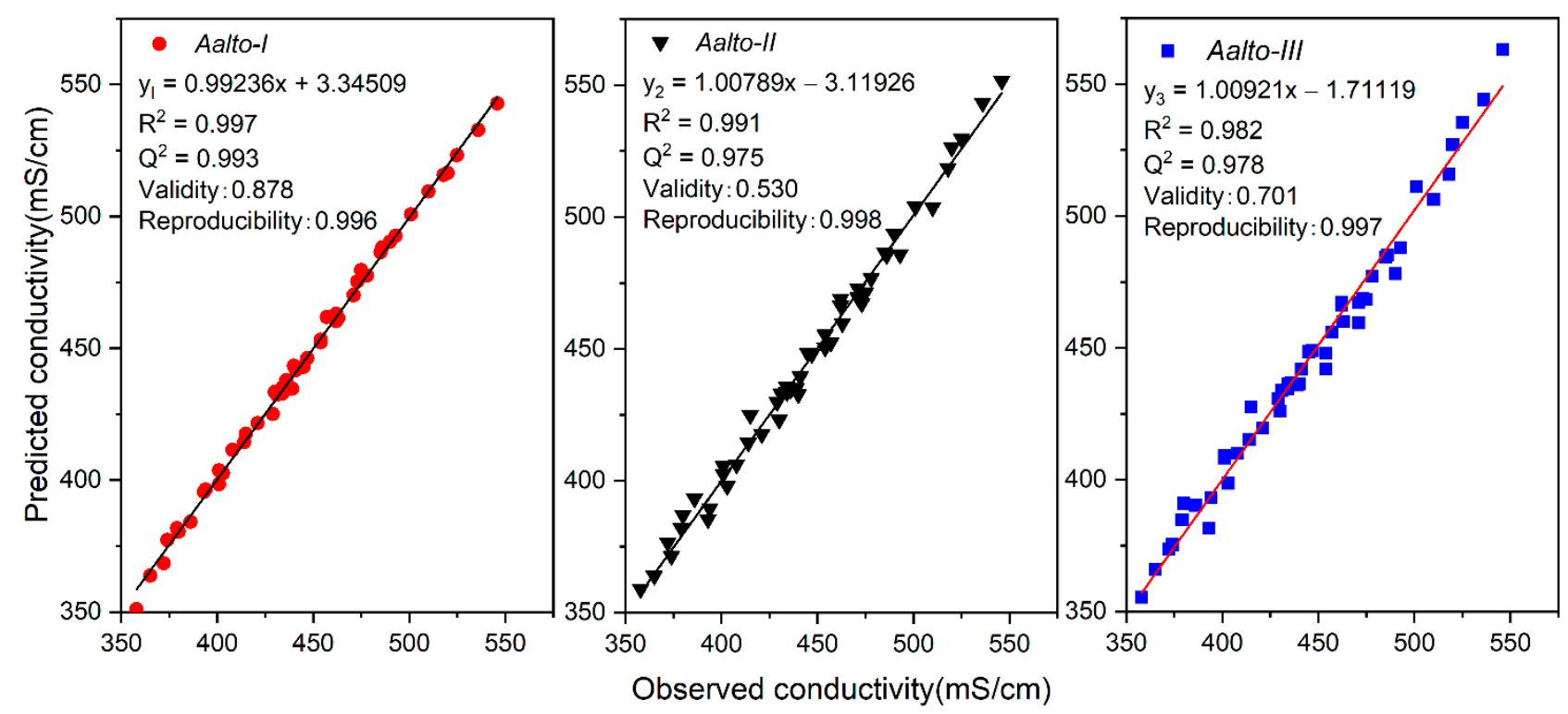

Figure 4. Measured (synthetic Zn electrolyte) vs. predicted conductivity by models Aalto-I, II and III.

According to Aalto-I, increases in both temperature and $\mathrm{H}_{2} \mathrm{SO}_{4}$ have a positive effect on conductivity, whereas the presence of metal ions ( $\mathrm{Zn}, \mathrm{Mn}, \mathrm{Mg}$ ) has a negative impact on solution conductivity. These findings are in agreement with earlier studies of $\mathrm{Zn}$ electrowinning conductivity [15,24-26], and are similar to the behavior found for $\mathrm{Cu}, \mathrm{Ni}$, and As, in copper electrowinning electrolytes [22].

\subsection{Comparison of Models with Synthetic Solutions}

A comparison of the Aalto-I model with those available in the literature (Figure 5), demonstrates a significant improvement in the calculation accuracy. Interestingly, the model from Mahon et al. [16], with the second-order full-factorial correlation (Equation (12)), shows good accuracy whilst having lower linearity than the model Aalto-I. On the other hand, the model proposed by Scott et al. [18] shows excellent linearity, even though it results in much higher calculated conductivities than the observed values. The overcalculation of the Scott et al. [18] model may result from the fact that the coefficients of the metal ions are set to a single value, rather than allowing each different ion type to contribute individually, which results in the deviation of the values. In comparison, whilst Aalto-I is shown to have a slight advantage with synthetic electrolyte conductivity measurements, further validation of the real industrial electrolytes of the available models is required to determine the most representative model.

\subsection{Industrial Validation}

A further comparison of Aalto-I with the models from previous studies, based on the industrial electrolyte results (Table S2), was carried out, as shown in Figure 6. This comparison in the industrial electrolytes shows that the Aalto-I model quite clearly deviates from the other models examined. As can be seen in Figure 6, Aalto-I offers the best accuracy and linearity for the electrolyte qualities used in industry. The significance of the improvement can be seen with the help of the ideal (dotted) line, showing an ideal correlation $(\mathrm{Y}=\mathrm{x})$. In contrast, the presence of other concentrations in the real electrolyte that were not taken into account during the model development, such as $\mathrm{Na}$ and $\mathrm{Ca}$, only result in a non-significant deviation. 


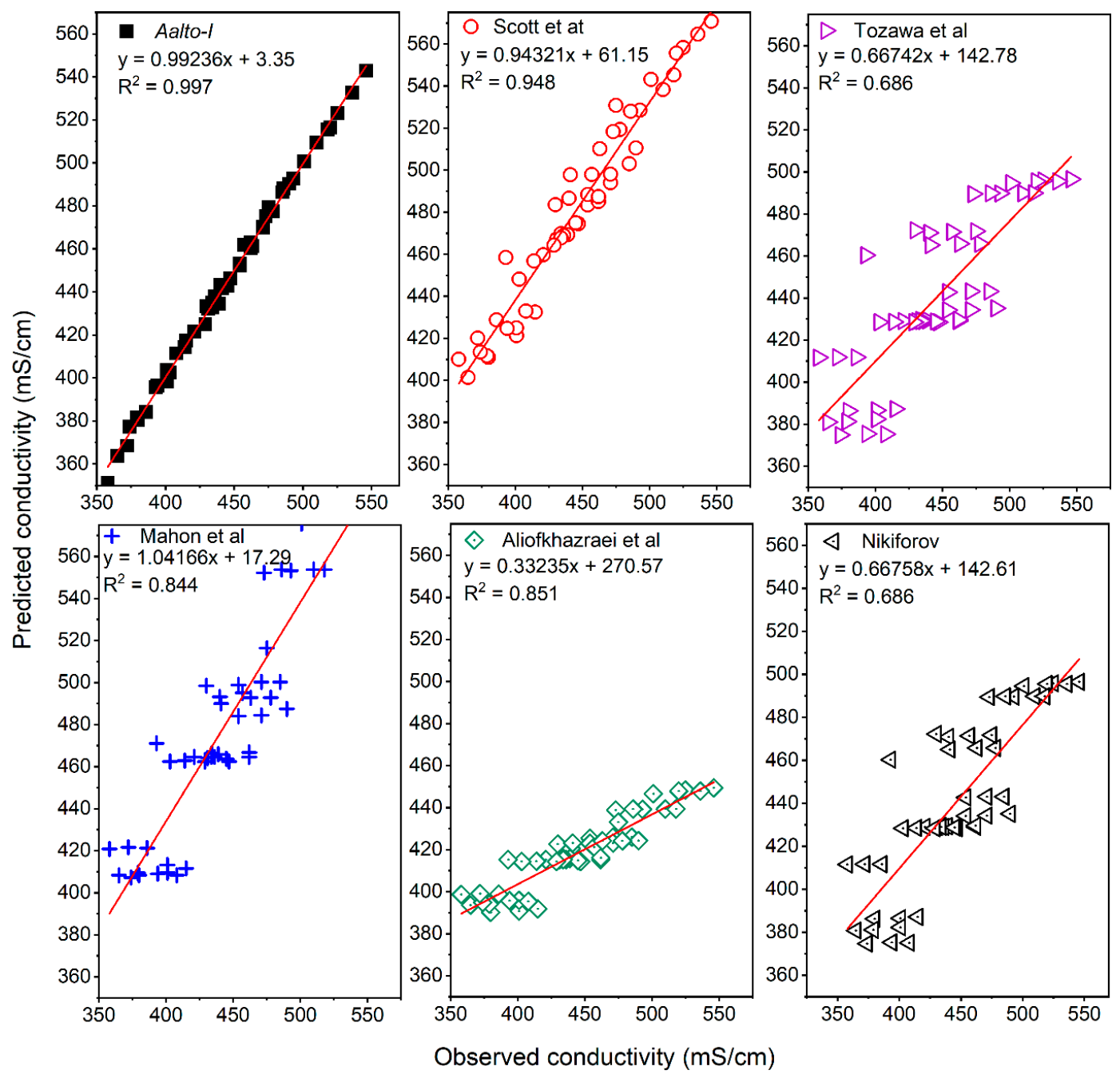

Figure 5. Measured (synthetic Zn electrolyte) vs. predicted conductivity by Nikiforov et al. (1971), Scott et al. (1988), Mahon et al. (2012), Tozawa et al. (1993), and Aliofkhazraei et al. (2007) [15-19].

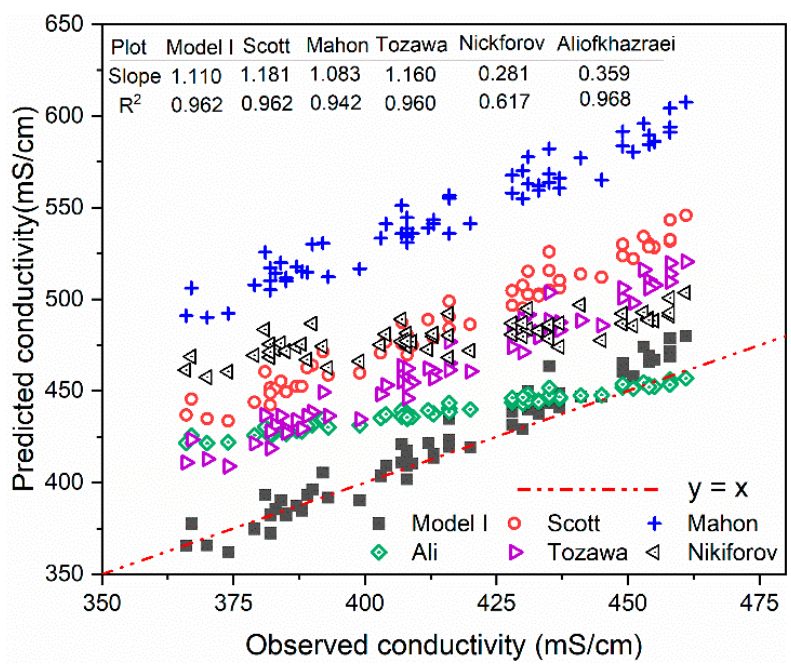

Figure 6. Measured vs. predicted conductivity for industrial Zn electrolyte determined by the earlier published models of Nikiforov et al. (1971), Scott et al. (1988), Mahon et al. (2012), Tozawa et al.(1993) and Aliofkhazraei et al. (2007) [15-19] and by the current Aalto-I model. 


\subsection{Model Utilization}

An approach to calculate the ohmic drop of the electrolyte $\left(E_{\text {ohmic }}\right)$ during zinc electrowinning can be conducted by combining the equation of model Aalto-I with Equation (8), as shown in Equation (18). The sensitivity analysis result with the center point: $60 \mathrm{~g} / \mathrm{dm}^{3} \mathrm{Zn}, 175 \mathrm{~g} / \mathrm{dm}^{3} \mathrm{H}_{2} \mathrm{SO}_{4}, 4 \mathrm{~g} / \mathrm{dm}^{3} \mathrm{Mn}, 2 \mathrm{~g} / \mathrm{dm}^{3} \mathrm{Mg}$, at a temperature of $35^{\circ} \mathrm{C}$, is shown by Figure 7 . The selected value varied by $\pm 15 \%$, and its effect on the conductivity was observed.

$$
E_{\text {ohmic }}=\frac{j l}{\left(129.239-2.657[\mathrm{Zn}]+1.687\left[\mathrm{H}_{2} \mathrm{SO}_{4}\right]+5.658 T-2.802[\mathrm{Mn}]-8.116[\mathrm{Mg}]\right)}
$$

where $j$ is in $\mathrm{mA} / \mathrm{cm}^{2}, l$ is in $\mathrm{cm}$, concentrations are in $\mathrm{g} / \mathrm{cm}^{3}$, and $T$ is in ${ }^{\circ} \mathrm{C}$.

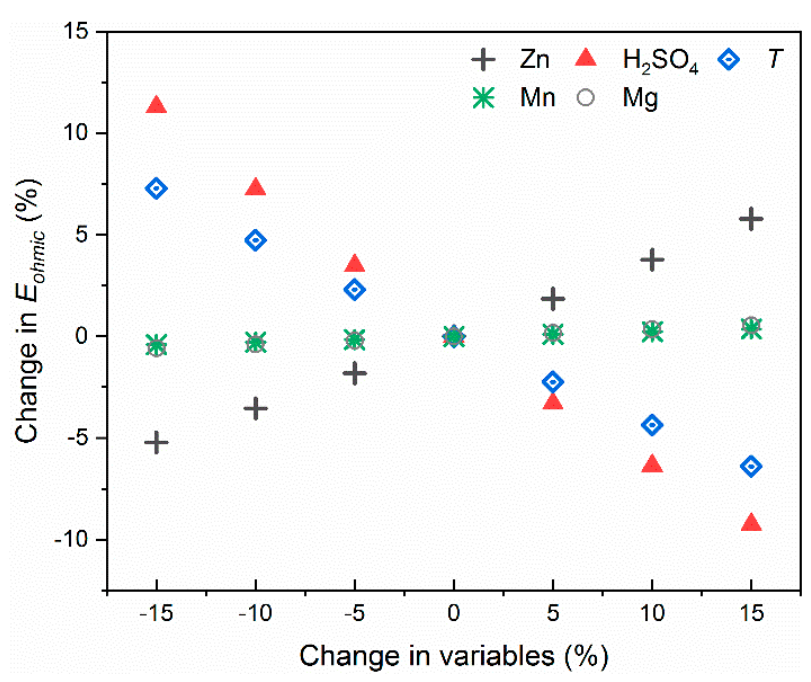

Figure 7. Effect of variable changes on the level of ohmic drop ( $\left.E_{\text {ohmic }}\right)$ predicted by Aalto-I.

It can be seen that both the increase in $\left[\mathrm{H}_{2} \mathrm{SO}_{4}\right]$ and $\mathrm{T}$ lowered the $E_{\text {ohmic }}$ value, whereas an increase in the concentration of metal ions (in particular $\mathrm{Zn}$ ) increased the level of ohmic drop. The variation from the defined $\mathrm{H}_{2} \mathrm{SO}_{4}$ concentration $\left(175 \mathrm{~g} / \mathrm{dm}^{3} \mathrm{H}_{2} \mathrm{SO}_{4}\right)$ has the most significant influence on $E_{\text {ohmic }}$ in the investigated parameter magnitude, while the effects of $T$ and $[\mathrm{Zn}]$ are slightly lower. These findings suggest that increases in temperature, and/or acid concentration, can be considered to effectively decrease the electrolyte ohmic drop.

In some cases, the bleeding of metal ions with high concentrations should also be considered to alleviate issues related to ohmic drop. For example, Boliden Odda Zinc Smelter has a relatively high acid concentration (ca. $190 \mathrm{~g} / \mathrm{L}$ ) and temperature $\left(\mathrm{ca} .40{ }^{\circ} \mathrm{C}\right.$ ), and a low zinc concentration (ca. $50 \mathrm{~g} / \mathrm{L}$ ). Mn concentration in the electrolyte is maintained at between 7 and $8 \mathrm{~g} / \mathrm{dm}^{3}$ in order to produce the $\mathrm{MnO}_{2}$ layer required for the corrosion protection of the $\mathrm{Pb}-\mathrm{Ag}$ anodes [27-29]. However, the high concentration of $\mathrm{Mg}\left(11-12 \mathrm{~g} / \mathrm{dm}^{3}\right)$, besides causing the blockage of pipe systems [30-32] and difficulties in the mass-transfer process of zinc deposition [33], could also create extra electrolyte overpotential. From Aalto-I and Equation (18), approximately 15\% of the electrolyte ohmic drop can be reduced by lowering the $\mathrm{Mg}$ concentration from $11.2 \mathrm{~g} / \mathrm{dm}^{3}$ to $2 \mathrm{~g} / \mathrm{dm}^{3}$. Furthermore, the model Aalto-I results based on the published data of $\mathrm{Zn}$ electrorefining show a large deviation of the ohmic drop contribution to the cell potential, from the lowest at app. $6.1 \%$-as discussed by We et al.—to more than double for the highest contribution to cell potential of $14.8 \%$ (outlined by Yanqing et al.) [13,18,34-44], as shown in Table 3 . 
Table 3. Zinc electrowinning operating conditions and calculated $E_{\text {ohmic }}$.

\begin{tabular}{|c|c|c|c|c|c|c|c|c|c|c|}
\hline \multicolumn{7}{|c|}{ Parameters } & \multirow{2}{*}{$\begin{array}{c}\text { Calculated } \\
E_{\text {ohmic }} \\
\text { (V) }\end{array}$} & \multirow[b]{2}{*}{$\begin{array}{l}E_{c e l l} \\
\text { (V) }\end{array}$} & \multirow[b]{2}{*}{ Ref. } & \multirow[b]{2}{*}{$\underset{(\%)}{E_{\text {ohmic }} / E_{\text {cell }}}$} \\
\hline $\begin{array}{c}{[\mathrm{Zn}]} \\
\mathrm{g} / \mathrm{dm}^{3}\end{array}$ & $\begin{array}{c}{\left[\mathrm{H}_{2} \mathrm{SO}_{4}\right]} \\
\mathrm{g} / \mathrm{dm}^{3}\end{array}$ & $\begin{array}{c}\mathrm{T} \\
{ }^{\circ} \mathrm{C}\end{array}$ & $\begin{array}{c}\mathrm{Mn} \\
\mathrm{g} / \mathrm{dm}^{3}\end{array}$ & $\underset{\mathrm{g} / \mathrm{dm}^{3}}{\mathrm{Mg}}$ & $\begin{array}{c}1 / \\
\mathrm{cm}\end{array}$ & $\begin{array}{c}\mathrm{j} \\
\mathrm{mA} / \mathrm{cm}^{2}\end{array}$ & & & & \\
\hline 60 & 180 & 38 & 8 & 0 & 2.0 & 50 & 0.21 & 2.898 & [34] & 7.4 \\
\hline 55 & 155 & 40 & 0 & 0 & 2.5 & 40 & 0.21 & 2.89 & [35] & 7.4 \\
\hline 55 & 150 & 40 & 0 & 0 & 3.0 & 40 & 0.26 & $2.91-2.98$ & [36] & 8.7 \\
\hline 50 & 150 & 35 & 5 & 0 & 2.0 & 50 & 0.23 & $3.22-3.8$ & [37] & 6.1 \\
\hline 50 & 210 & 45 & 4.6 & 12.2 & 3.8 & 40 & 0.31 & 3.21 & [18] & 9.6 \\
\hline 62 & 190 & 38 & 0 & 0 & 2.5 & 50 & 0.25 & $2.91-2.99$ & [38] & $8.4-8.6$ \\
\hline 58 & 160 & 38 & 0 & 0 & 2.5 & 50 & 0.27 & 3.03 & [39] & 9 \\
\hline 55 & 165 & $38-42$ & 3.5 & 15.87 & 3 & 50 & $0.42-0.44$ & $3.0-3.25$ & [40] & $12.8-14.8$ \\
\hline $48-52$ & 170-190 & 35 & 0 & 0 & 3.5 & 58 & $0.39-0.44$ & 3.45 & [41] & $11.3-12.4$ \\
\hline 65 & 150 & 35 & 5 & 0 & 3.5 & 50 & 0.44 & 3.15 & [42] & 14.1 \\
\hline 50 & 150 & 38 & 3 & 0 & 3.0 & 50 & 0.33 & $3.28-3.31$ & [43] & 10 \\
\hline 50 & 160 & 35 & 2 & 0 & 3.0 & 50 & 0.33 & $2.66-2.82$ & [44] & $11.6-12.3$ \\
\hline 61.5 & 171 & 38 & 5.2 & 5.31 & 2.5 & 50 & 0.30 & $3.00-3.05$ & [13] & $10.0-10.1$ \\
\hline
\end{tabular}

It is worth noting, however, that the above discussions are primarily focused on the cell voltage and ohmic drop, whilst optimal operating parameters are the complex result of many other factors. For instance, high acid concentration may increase the likelihood for hydrogen evolution, and reverse zinc dissolution, leading to a decrease in the current efficiency, while elevated temperature would cause nodule formation [18]. Consequently, the comprehensive effects of electrode reactions, and electrolyte ohmic drop, should be evaluated in detail during parameter optimization.

\section{Conclusions}

The three zinc electrolyte conductivity models constructed in this study were found to have good validities, and high correlation coefficients (Aalto I-III). Furthermore, Aalto-I was shown to offer a significant improvement to the accuracy of prediction when compared to the previously published models, due to the inclusion of individual coefficients for each metal present, rather than as a single collective effect of all metals. The industrial validation of the models-conducted at the Boliden Odda facility in Norway-further demonstrated the high accuracy of the Aalto-I conductivity model. Even though the effects of minor impurities ( $\mathrm{Na}$ and $\mathrm{Ca}$ ) were excluded during the development of the model, the model can accurately predict conductivity. This indicates that the parameters and levels taken into account within the model development were representatives of the real conditions present in industrial processes. Consequently, Aalto-I can be used as an effective tool for the prediction of electrolyte conductivity, and the optimization of industrial zinc electrowinning processes.

Supplementary Materials: The following are available online at https: / www.mdpi.com/article / 10.3390/met11111824/s1, Table S1: Raw data obtained from the conductivity measurements of the synthetic zinc electrolytes. Table S2: Conductivity measurements of industrial electrolytes from the electrowinning cells at different temperatures.

Author Contributions: Z.W.: conceptualization, writing—original draft preparation; A.T.A.: writingreview and editing; B.P.W.: writing—review and editing; S.J. and M.M.: validation; M.L.: project administration, funding acquisition and resources. All authors have read and agreed to the published version of the manuscript.

Funding: GoldTail (project number, 319691); Symmet (project number, 2117441); Tocanem (project number, 2118451).

Data Availability Statement: Data regarding this article is available from the corresponding author upon a reasonable request. 
Acknowledgments: Grateful thanks to Boliden Odda Zinc Smelter for allowing field measurements to be undertaken at their plant. The RawMatTERS Finland Infrastructure (RAMI) funded by Academy of Finland and based at Aalto University is also acknowledged.

Conflicts of Interest: The authors declare no conflict of interest.

\section{References}

1. O'Keefe, T.J. Zinc electrowinning-short course. In Lead Zinc 2000 Symposium; John Wiley \& Sons: Pittsburgh, PA, USA, 2000.

2. Stefanov, Y.; Dobrev, T. Potentiodynamic and electronmicroscopy investigations of lead-cobalt alloy coated lead composite anodes for zinc electrowinning. Trans. IMF 2005, 83, 296-299. [CrossRef]

3. Jin, L.; Huang, H.; Fei, Y.; Yang, H.; Zhang, H.; Guo, Z. Polymer anode used in hydrometallurgy: Anodic behaviour of PANI $/ \mathrm{CeO}_{2} / \mathrm{WC}$ anode from sulfate electrolytes. Hydrometallurgy 2018, 176, 201-207. [CrossRef]

4. Rashkov, S.; Dobrev, T.; Noncheva, Z.; Stefanov, Y.; Rashkova, B.; Petrova, M. Lead-cobalt anodes for electrowinning of zinc from sulphate electrolytes. Hydrometallurgy 1999, 52, 223-230. [CrossRef]

5. Karbasi, M.; Alamdari, E.K.; Dehkordi, E.A. Electrochemical performance of PbCo composite anode during zinc electrowinning. Hydrometallurgy 2019, 183, 51-59. [CrossRef]

6. Li, H.; Chen, Z.; Yu, Q.; Zhu, W.; Cui, W. Effects of tungsten carbide on the electrocatalytic activity of PbO2-WC composite inert anodes during zinc electrowinning. J. Electrochem. Soc. 2017, 164, H1064-H1071. [CrossRef]

7. Zhang, C.; Liu, J.; Chen, B. Effect of $\mathrm{CeO}_{2}$ and graphite powder on the electrochemical performance of $\mathrm{Ti} / \mathrm{PbO}_{2}$ anode for zinc electrowinning. Ceram. Int. 2018, 44, 19735-19742. [CrossRef]

8. Chen, B.; Wang, S.; Liu, J.; Huang, H.; Dong, C.; He, Y.; Yan, W.; Guo, Z.; Xu, R.; Yang, H. Corrosion resistance mechanism of a novel porous $\mathrm{Ti} / \mathrm{Sn}-\mathrm{Sb}-\mathrm{RuO}_{\mathrm{x}} / \beta-\mathrm{PbO}_{2}$ anode for zinc electrowinning. Corros. Sci. 2018, 144, 136-144. [CrossRef]

9. Zhang, T.; Morimitsu, M. A novel oxygen evolution anode for electrowinning of non-ferrous metals. In Electrometallurgy 2012; John Wiley \& Sons, Ltd.: Pittsburgh, PA, USA, 2012; pp. 29-34, ISBN 978-1-118-37135-0.

10. Morimitsu, M. Performance and commercialization of the smart anode, $\mathrm{MSA}^{\mathrm{TM}}$, for environmentally friendly electrometallurgical process. In Electrometallurgy 2012; John Wiley \& Sons, Ltd.: Pittsburgh, PA, USA, 2012; pp. 49-54, ISBN 978-1-118-37135-0.

11. Ivanov, I.; Stefanov, Y.; Noncheva, Z.; Petrova, M.; Dobrev, T.; Mirkova, L.; Vermeersch, R.; Demaerel, J.-P. Insoluble anodes used in hydrometallurgy: Part II. anodic behaviour of lead and lead-alloy anodes. Hydrometallurgy 2000, 57, 125-139. [CrossRef]

12. Ivanov, I.; Stefanov, Y.; Noncheva, Z.; Petrova, M.; Dobrev, T.; Mirkova, L.; Vermeersch, R.; Demaerel, J.-P. Insoluble anodes used in hydrometallurgy: Part I. corrosion resistance of lead and lead alloy anodes. Hydrometallurgy 2000, 57, 109-124. [CrossRef]

13. Alfantazi, A.M.; Dreisinger, D.B. The role of zinc and sulfuric acid concentrations on zinc electrowinning from industrial sulfate based electrolyte. J. Appl. Electrochem. 2001, 31, 641-646. [CrossRef]

14. Brett, C.M.A.; Brett, A.M.O. Electrochemistry: Principles, Methods, and Applications; Oxford University Press: Oxford, UK, 1993; ISBN 978-0-19-855388-5.

15. Aliofkhazraei, M.; Alamdari, E.K.; Zamanzade, M.; Salasi, M.; Behrouzghaemi, S.; Heydari, J.; Haghshenas, D.F.; Zolala, V. Empirical equations for electrical conductivity and density of $\mathrm{Zn}, \mathrm{Cd}$ and $\mathrm{Mn}$ sulphate solutions in the range of electrowinning and electrorefining electrolytes. J. Mater. Sci. 2007, 42, 9622-9631. [CrossRef]

16. Mahon, M.; Wasik, L.; Alfantazi, A. Development and implementation of a zinc electrowinning process simulation. J. Electrochem. Soc. 2012, 159, D486-D492. [CrossRef]

17. Nikiforov, A.F.; Natarova, E.L. A formula to calculate the specific conductivity of zinc electrolyte. Tsvetnaya Metall. 1971, 44, 28.

18. Scott, A.C.; Pitblado, R.M.; Barton, G.W.; Ault, A.R. Experimental determination of the factors affecting zinc electrowinning efficiency. J. Appl. Electrochem. 1988, 18, 120-127. [CrossRef]

19. Tozawa, K.; Umetsu, Y.; Su, Q. World Zinc'93, Proceedings of the International Symposium on Zinc. Australasian Institute of Mining and Metallurgy Publication Series 7/93, Hobart, Australia, 10-13 October 1993; Australasian Institute of Mining and Metallurgy: Parkville, Australia, 1993.

20. Aji, A.T.; Kalliomäki, T.; Wilson, B.P.; Aromaa, J.; Lundström, M. Modelling the effect of temperature and free acid, silver, copper and lead concentrations on silver electrorefining electrolyte conductivity. Hydrometallurgy 2016, 166, 154-159. [CrossRef]

21. Lehtiniemi, I.; Kalliomäki, T.; Rintala, L.; Latostenmaa, P.; Aromaa, J.; Forsén, O.; Lundström, M. Validation of electrolyte conductivity models in industrial copper electrorefining. Min. Metall. Explor. 2018, 35, 117-124. [CrossRef]

22. Kalliomäki, T.; Aromaa, J.; Lundström, M. Modeling the effect of composition and temperature on the conductivity of synthetic copper electrorefining electrolyte. Minerals 2016, 6, 59. [CrossRef]

23. Eriksson, L.; Johansson, E.; Kettaneh-Wold, N.; Wikström, C.; Wold, S. Design of Experiments: Principles and Applications; MKS Umetrics AB: Umeå, Sweden, 2008; Volume 2008, p. 78.

24. Aliofkhazraei, M. Study of electrical conductivity for electrolytes of electrowinning and electrorefining processes. Russ. J. Non-ferrous Metals 2009, 50, 97-101. [CrossRef]

25. Barton, G.W.; Scott, A.C. A Validated mathematical model for a zinc electrowinning cell. J. Appl. Electrochem. 1992, 22, 104-115. [CrossRef]

26. Hinatsu, J.T.; Tran, V.D.; Foulkes, F.R. Electrical conductivities of aqueous $\mathrm{ZnSO}_{4}-\mathrm{H}_{2} \mathrm{SO}_{4}$ solutions. J. Appl. Electrochem. 1992, 22, 215-223. [CrossRef] 
27. MacKinnon, D.J.; Brannen, J.M. Effect of manganese, magnesium, sodium and potassium sulphates on zinc electrowinning from synthetic acid sulphate electrolytes. Hydrometallurgy 1991, 27, 99-111. [CrossRef]

28. Mahon, M.; Alfantazi, A. Manganese consumption during zinc electrowinning using a dynamic process simulation. Hydrometallurgy 2014, 150, 184-191. [CrossRef]

29. Mohammadi, M.; Alfantazi, A. Evaluation of manganese dioxide deposition on lead-based electrowinning anodes. Hydrometallurgy 2016, 159, 28-39. [CrossRef]

30. Booster, J.L.; Van Sandwijk, A.; Reuter, M.A. Magnesium removal in the electrolytic zinc industry. Miner. Eng. 2000, 13, 517-526. [CrossRef]

31. Georgalli, G.A.; Eksteen, J.J.; Pelser, M.; Lorenzen, L.; Onyango, M.S.; Aldrich, C. Fluoride based control of Ca and Mg concentrations in high ionic strength base metal sulphate solutions in hydrometallurgical circuits. Miner. Eng. 2008, 21, 200-212. [CrossRef]

32. Sharma, K.D. An approach to reduce magnesium from zinc electrolyte with recovery of zinc from disposed residue of an effluent treatment plant. Hydrometallurgy 1990, 24, 407-415. [CrossRef]

33. Tian, L.; Xie, G.; Yu, X.-H.; Li, R.-X.; Zeng, G.-S. Effect of magnesium ion on the zinc electrodeposition from acidic sulfate electrolyte. Met. Mat Trans. A 2012, 43, 555-560. [CrossRef]

34. Sorour, N.; Zhang, W.; Gabra, G.; Ghali, E.; Houlachi, G. Electrochemical studies of ionic liquid additives during the zinc electrowinning process. Hydrometallurgy 2015, 157, 261-269. [CrossRef]

35. Zhang, Q.; Hua, Y. Effects of 1-Butyl-3-Methylimidazolium hydrogen sulfate-[BMIM]HSO $\mathrm{H}_{4}$ on zinc electrodeposition from acidic sulfate electrolyte. J. Appl. Electrochem. 2009, 39, 261-267. [CrossRef]

36. Tripathy, B.C.; Das, S.C.; Singh, P.; Hefter, G.T.; Misra, V.N. Zinc electrowinning from acidic sulphate solutions part IV1Part I, part II and part III Are Published in J. Appl. Electrochem, 27 (1997) 673, 28 (1998) 915, 29 (1999) 1229, respectively.1: Effects of Perfluorocarboxylic Acids. J. Electroanal. Chem. 2004, 565, 49-56. [CrossRef]

37. Wu, X.; Liu, Z.; Liu, X. The effects of additives on the electrowinning of zinc from sulphate solutions with high fluoride concentration. Hydrometallurgy 2014, 141, 31-35. [CrossRef]

38. Alfantazi, A.M.; Dreisinger, D.B. An investigation on the effects of orthophenylene diamine and sodium lignin sulfonate on zinc electrowinning from industrial electrolyte. Hydrometallurgy 2003, 69, 99-107. [CrossRef]

39. Majuste, D.; Martins, E.L.C.; Souza, A.D.; Nicol, M.J.; Ciminelli, V.S.T. Role of organic reagents and impurity in zinc electrowinning. Hydrometallurgy 2015, 152, 190-198. [CrossRef]

40. Yanqing, L.; Liangxing, J.; Jie, L.; Shuiping, Z.; Xiaojun, L.; Hongjian, P.; Yexiang, L. A novel porous Pb-Ag anode for energysaving in zinc electrowinning: Part II: Preparation and pilot plant tests of large size anode. Hydrometallurgy 2010, 102, 81-86. [CrossRef]

41. Bouzek, K. Current distribution at the electrodes in zinc electrowinning cells. J. Electrochem. Soc. 1995, 142, 64. [CrossRef]

42. Huang, H.; Zhou, J.; Chen, B.; Guo, Z. Polyaniline anode for zinc electrowinning from sulfate electrolytes. Trans. Nonferrous Met. Soc. China 2010, 20, s288-s292. [CrossRef]

43. Chen, B.; Yan, W.; He, Y.; Huang, H.; Leng, H.; Guo, Z.; Liu, J. Influence of F-doped $\beta-\mathrm{PbO}_{2}$ conductive ceramic layer on the anodic behavior of 3D Al/Sn Rod Pb-0.75\%Ag for zinc electrowinning. J. Electrochem. Soc. 2019, 166, E119-E128. [CrossRef]

44. Wang, S.; Zhou, X.; Chi-Yuan, M.; Long, B.; Wang, H.; Tang, J.-J.; Yang, J. Electrochemical properties of Pb-0.6 wt\% Ag powderpressed alloy in sulfuric acid electrolyte containing $\mathrm{Cl}^{-} / \mathrm{Mn}^{2+}$ ions. Hydrometallurgy 2018, 177, 218-226. [CrossRef] 